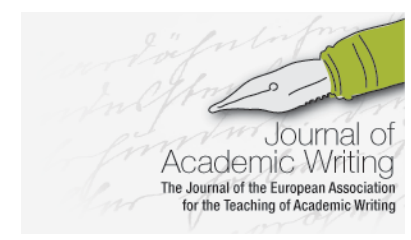

Journal of Academic Writing

Vol. 8 No 2 Winter 2018, pages 1-10 http://dx.doi.org/10.18552/joaw.v8i2.531

\title{
On the Privatisation of Academic Writing Development: A Post-EATAW 2017 Provocation
}

\author{
Catalina Neculai \\ Coventry University, United Kingdom
}

\begin{abstract}
All across continental Europe and the United Kingdom, academic writing teaching or development is slowly becoming part and parcel of existing institutional frameworks intended to enhance student writing and professional research communication. While more and more universities are investing in such infrastructures of support internally, a relatively new phenomenon is also consolidating: the steady rise of privatised, for-profit writing development businesses that draw their client base from academic institutions. Prompted by EATAW 2017, the conference organised at Royal Holloway, University of London, this think piece raises some fundamental questions regarding the privatisation of academic writing development and invites colleagues to consider its assumptions, emergence and implications in their local higher education contexts.
\end{abstract}

\section{Introduction}

A few years ago, during a Christmas holiday visit to my home city in Romania, a colleague running an MA programme at my alma mater kindly asked if I would be willing to teach a session on academic writing to their MA students in the last week of the term. This request was part of a conversation she and I had about my writing development work with students and staff in our Centre for Academic Writing. That work, my work, was perceived by her as a privilege as she expressed the desire for similar work to be done in their department. I, on the other hand, perceived her invitation to offer that session as a duty of care. After all, I first learnt about (doing) academic writing in that department back in the early 1990s as an undergraduate student studying for a degree in English and French. I responded positively to the invitation and delivered, pro bono, a two-hour seminar to a room full of students who attended with utmost interest despite being eager to break off for their winter holiday.

While it was both needed and appreciated there and then as a gateway to learning about advanced academic writing in English, I was not certain of the real impact of that one-off session. I did not collect feedback, nor did I assess student satisfaction rates as per the requirements of teaching in Western neoliberal academia. There was no follow-up either. In fact, I am not a great believer in the efficacy of workshops, so I rarely feel I make a difference by teaching them - the real writing labour, the real shifts in 'text histories' (Lillis and Curry 2010) happen at the level of micro-practices, in the lab, as it were. No matter its impact, I was certain that, had the session been commissioned via the usual interuniversity transactional channels with the added profit margins, it would, most likely, not have happened at all because it would have been prohibitive for colleagues and their students in Romania. The scarcity of institutional resources in the semi-periphery (Bennett 2014, amongst others) makes of academic writing development a luxury good, yet one that easily circulates across national borders. It can thus be argued that my delivery of this session fitted an 'export-import model' of teaching writing whereby 'deprived' academic communities were making use of the 'foreign expert' (Donahue 2009, Harbord 2008 cited in Donahue 2009: 222) to compensate for lack of provision; therefore, a certain kind of imposition (invasion?) took place. However, the pro bono nature of the teaching 
and my local, non-Anglophone identity also defied that model and thus rendered the situation more nuanced and less amenable to such colonial-minded interpretations.

This is just one anecdote among many that can be told about developing writing away from home. I have since heard of other Romanian researchers in the UK who go back to their parent universities to teach modes of academic writing in English pro bono. It goes without saying that such interventions reflect complex issues at stake in the material and linguistic conditions of academic writing development in the globalised world of education and research, especially the inequities that characterise access to the knowledge and practice of academic writing. As Deborah Brandt rightly argues, following Bourdieu, 'linguistic insecurity, like food insecurity, is manufactured politically through the unjust manipulation of power' (2017: 269-70). The entanglements in power structures are often hidden or taken for granted in the practice of academic writing; hence the calls in Academic Literacies research to define and make explicit the implicitly political; hence the recent work devoted to the close reading of the material circumstances of academic writing as labour, pedagogies, development, production and dissemination (amongst many others, the work of Bruce Horner, Suresh Canagarajah, Theresa Lillis and Mary Jane Curry, Karen Bennett, Deborah Brandt, Christian Chun, Ken Hyland, Karen Englander). My critical reflections on the corporatisation of academic writing are situated in this territory of research and stem from a deep-seated belief in the publicness and accessibility of academic writing which I understand in terms of both an individual and collective right to academic literacies and the conditions of academic justice necessary for these rights to materialise (following Lefebvre's 1968 'right to the city').

Three lines of discussion unfold hereafter. The first uses my participation in a recent online seminar on the knowledge and state of global academic publishing to scaffold my positionality regarding the sensitive public/private double bind of academic writing. In doing so, I also argue that it is crucial to our profession to create open and critical spaces of debate, often via 'unclassified writing' (REF 2014) (like this piece and the responses to it!), to address the uneven and occluded access to writing development. Some of my ideas in this provocation were crystallised during that seminar. Against this backdrop, I then look back in hope but also critique, at the EATAW 2017 conference to understand the importance accorded to the politics and policies of academic writing, but also to find in its neglected margins (both material and symbolic) signs of corporatisation in a sea of public-minded academic writing work. The third section zooms in to the commodified nature of for profit writing development by examining the rise of the corporate, external writing expert, some of the consequences on the development of academic writing in higher education institutions, and proposed ways of mitigating these.

One caveat is, however, necessary. As I write elsewhere (see the seminar debates discussed below), working in a writing centre that is predicated on the notion of support, I am interested in processes used to name the nature of writing development work and identity, while seeking to problematise the tensions between disciplinary constructions of knowledge and the institutional positioning of the academic writing developer outside of the disciplines. In some sense, I resolve this tension in my own role by working in the fields of both academic writing and urban cultural geography. I fully acknowledge that academic writing developers, advisors, brokers, teachers or coaches (the terms multiply!) can be instrumental in commodifying research writing by serving, often uncritically, the institutional regimes of writing, especially research writing, (re)production and evaluation. Yet, through writing development, we can also create spaces of reflection, critique and internal revision of the pitfalls of these regimes, by inviting explicit conversations on the conditions of writing labour and its symbolic superstructures in the transnational academy, or by rethinking the pedagogies used to reproduce the knowledges and conventions of research writing. This piece is such an invitation.

Then, of course, I also fully recognise that academic writing support represents a set of practices dependent on investment and the circulation of a research writing development capital, often a spin-off of other capital circuits like tuition fees, project funding streams and public budgets. On a macro-institutional level, it is hard to disentangle the labour of teaching writing from the labour of (developing) research writing, or to separate research writing development from the financial regimes that support it, which means that a revisionist stance may also be harder to achieve. But research writing development work in universities is also 
caught, rather uncomfortably, in another public/private double bind through the increased privatisation of writing development outside of academic institutions that makes its way into universities, through outsourcing and the purchasing of writing development services like workshops or retreats. This is the material reality my provocation would like to scaffold first, and then unravel. All throughout the paper, I foreground the questions and dilemmas that I find pressing, often without adopting final positions or conclusions.

\section{Debating the Rights to Academic Literacies: In Defence of Unclassified Writing}

One area where the rights to academic literacies are egregiously uneven is research writing across institutional and national borders. To address this unevenness, researchers in the International Association of Applied Linguistics have created a network dedicated to 'academic publishing and presenting in a global context' (AILA ReN). In February 2018, in partnership with the 'Professional academic and work-based literacies' Special Interest Group of the British Association of Applied Linguistics (BAAL PAWBL SIG), AILA ReN ran a month-long online seminar on our state of knowledge about academic publication practices (AILA ReN and BAAL PAWBL SIG 2018a). Convened by Theresa Lillis, the seminar was based on invited responses to three papers (Hyland 2016; Moreno et al. 2012; Cardenás and Rainey 2017) followed by other participants' contributions to the dialogues.

To summarise the paper discussions briefly, the participants put forward much needed critical questions about: the hegemony of English as the medium of international publishing; genre and rhetorical evolutions; researchers' and gatekeepers' writing and publishing practices; (in)justice and structural (dis)advantage; writing development. The debates articulated a multitude of interrelated perspectives taking into account the material, discursive and linguistic conditions that shape participation in the public sphere of knowledge dissemination. The issues raised straddled the disciplinary boundaries of applied linguistics, cultural studies, rhetoric, writing studies, geography, sociology, thus highlighting the necessity for an integrated, complex approach to (professional) academic literacies. This integrated approach also included a substantial intermezzo on academic labour, a conversation led by Bruce Horner, Jackie Tuck and Sharon McCulloch. They drew attention to a host of labour-related issues such as the primacy of the exchange-value of writing (writing as object and commodity); the decontextualised promotion of writing as skill; the casualisation of academic (writing) labour; and the evaluative institutional structures that condition writing practices, form certain writerly identities, and lead to the use of particular writing technologies (see all the threads of AILA ReN and BAAL PAWBL SIG 2018).

The online seminar was one of those great opportunities where international researchers and teachers come together in acts of open dialogue and sustained scrutiny, not just of others' positions but also of their own. Dialogue and scrutiny then turn into acts of learning and reflection, and, ultimately, into a sense of belonging to a collective that is accessibly and horizontally organised against the grain of established institutional hierarchies, and exists on the frontlines of public, activist engagements with academic writing (for a manifesto on academic activism, see SIGJ2 Writing Collective 2012). Through its publicness as a Google Group discussion, the seminar became a cross-border space for collective co-constructions of knowledge, with its intrinsic hesitations, delays, emotions (coded electronically as emoticons), technological faux pas, disclaimers and caveats. As an invited respondent to Ken Hyland's paper on 'The Myth of Linguistic Injustice' (2016) and a willing participant in the conversation on academic labour, I found the seminar to be a 'hospitable writing space', to cite Jackie Tuck (AILA ReN and BAAL PAWBL SIG 2018b). In that space, I could voice my views, confront my own assumptions and limitations (especially the limitations of my readings) and take stock of those aspects of academic writing to which I pay attention in my own labour.

I find it important to recount and acknowledge this virtual seminar, and thus scaffold my provocation, for at least three reasons. First, such an ad-hoc dialogic, critical writing space is egalitarian and (re)visionary in nature (SIGJ2 Writing Collective 2012: 1056), at once inside and outside the space of the university, encouraged and neglected as legitimate academic labour or as academic writing that matters to institutional regulatory regimes that classify, measure 
and validate writing genres and practices. This extract from an exchange between Theron Muller and Bruce Horner speaks to such ambivalences:

Theron Muller: 'some of these very valuable and very worthwhile academic exchanges seem to not be officially encoded in the higher education value systems we find ourselves working in.'

Bruce Horner: '[it] might be possible to tweak institutional accounting categories to encourage more activities like this symposium.' (AILA ReN and BAAL PAWBL SIG 2018c)

The parallels are evident. My provocation piece is equally public in nature by virtue of the open access platform through which the Journal of Academic Writing is published and circulates. It also sits precisely in the same unmarked space of academic writing that, while important for sustaining intellectual conversations in the field, will not be as relevant to the evaluative systems of research writing in place. This piece, just like the online seminar discussions, constitutes 'unclassified writing', to use the language of the Research Excellence Framework (REF), the UK's system of research evaluation, ranking and funding allocation. On the one hand, unclassified writing marks 'quality that falls below the standard of nationally recognised work' in terms of significance, rigour, and originality (REF 2014). On the other hand, it refers to 'work which does not meet the published definition of research for the purposes of this assessment' (REF 2014). In the latter definition, unclassified thus refers to research genres other than the traditional, empirical or theoretical research article, and the monograph. Unclassified writing, therefore, evades classificatory regimes and can open a space of wilful resistance or at least create possibilities for alternative forms of academic writing.

Second, the concerns over the recognition or the ranking of certain forms of academic work and writing signal, in fact, a tension between public and private, open and gated forms of writing and knowledge production, dissemination and access, particularly pertinent to the evolving traditions of writing studies, writing development or rhetoric and composition (for the contested political economy of some of these traditions and their indeterminate conceptual domains in the United States, see for example the valuable work of Bousquet 2002, Abraham 2016, Horner 2000, Horner 2015). Writing about writing on the margins, or about the labour that produces, teaches and develops it, or about the governance of writing via policies and regulations like those of the REF, does mean engaging with the material and social conditions of writing in honest yet imperative ways. Research in this area is already rife in composition, EAP, academic literacies or global professional academic writing. Such work testifies to the complex implications of these 'economies of writing' (Horner, Nordquist and Ryan 2017) at the level of textual practice, identity and the mechanisms that support textual production at different levels, from student writing to published research.

Third, academic writing in all its dimensions is certainly characterised by a complex double bind: on the one hand, privileged, monetised, privatised, managed, regulated, surveilled, compliant, commodified, pragmatic, market-oriented; on the other hand, public, accessible, communal, deregulated, revisionist, intellectualised, critical, resistant, political, community-oriented. Reducible to the public-open/private-gated binary, in my experience, these opposing characteristics have the capacity to co-exist and even intermingle in the everyday routines of academic writing teaching and development, but also to cause concerns or frictions. In the specific context of the privatisation of academic writing development, either from within or from outside of academic institutions, such tensions are most evident which is why it becomes important to begin, at least, to address them. Only then can we also begin to envision any possibility for productive alliances between writing development businesses and universities, particularly where academic writing development is absent locally. In what follows, I will present some of these issues as they became apparent to me during the EATAW 2017 conference and then later, in my reflections. 


\section{EATAW 2017: Policy, Pedagogy, Practice... but also Politics and Privatisation}

Due to other commitments, I decided to attend the EATAW 2017 conference at the last minute and therefore as a non-presenting participant. Arguably, attending as an observer only, and as chair of two of the sessions, allowed me the luxury of more critical distance. I was mainly intrigued by the event's avowed focus on policy and its intertwining with writing pedagogies (or development) and practices. Since I think of policy as merely the tip of an ideological iceberg, to me, a focus on policy suggested a focus on politics, namely the EATAW collective's allegiances to certain ideological constructions of academic writing, its material conditions as well as its contributions to other material conditions in non-academic communities.

A strand of presentations caught my attention as they acknowledged the 'economic and political issues encroaching academia' (Ferenz and Goldfrad in EATAW 2017a: 16) and tackled the problem of oppressive, neoliberal and marketised cultures, academic and non-academic alike, in the age of post-truth. They debated the role of literacy, of writing centres and writing programmes in counteracting or counterbalancing these hegemonic institutional and societal structures in order to create: powerful inclusive literacies (Cain in EATAW 2017a: 2), activist participatory cultures of writing (Williams in EATAW 2017a: 25), writing spaces of diversity that resist reification (Bonazza, Thomas and Murialdo in EATAW 2017a: 7), critical pedagogies for writing education (Felix in EATAW 2017a: 20), local writing texts against the grain of commercial handbooks (Christoph and Young in EATAW 2017a: 150), or responsible and thoughtful citizenship through truth-seeking activities and the uses of classical and modern rhetoric (Schick and Schubert in EATAW 2017a: 78). The symposium on '21st century writing in a time of globalization' further capitalised on such political acts of teaching and developing writing. It accounted for the linguistic, political and socio-economic conditions of migration, national belonging, and identity, as well as for the knots of power that condition academic writing (Riedner, Wingard, Dingo and Schell in EATAW 2017a: 130).

Of course, policies matter. They are, after all, the actualisation of these writing politics and regulate the organisation of writing education and development at grassroots level. Engaging with policy, doing policy work, influencing policy, even writing policy (Murray at EATAW 2017b) are acts of making writing and its development visible. Rowena Murray made an apt and fullyfledged case for policy work in her opening keynote. However, the politics behind her argument did not seem to envisage the conversion of policy makers to our ways of seeing writing or the kinds of favourable writing policies that could, in her own words, 'shape society' or at least the academic institutions where we work. There was little critique of policy as we know it and its impact on writing; for example, policies derived from fixed ideologies of skill transferability, or from the commodification of writing as outcome and currency of exchange for career trajectories or funding streams (Horner 2000). In her talk, Murray did, in fact, eschew the politics behind the policies by admitting that the workings of the academic system do not leave much room for contestation or revision (by comparison, see Horner 2015). In her account, writing retreats could certainly be spaces for doing policy writing but can they be politically neutral writing spaces?

In another keynote, Ronald Barnett (EATAW 2017b) addressed the systemic question by referring to practices of 'gaming the system' - the tactics through which academics are forced to respond to the pressures of policy. However, Barnett's stance was not acquiescent; his defence of a public sphere facilitated through the practice and development of writing was unfaltering. Drawing on her own international experience, Katrin Girgensohn's plenary talk (EATAW 2017b) went further to unravel the hidden parts of the iceberg, speaking openly about the political siege on the Central European University, the current climates of austerity and budget cuts, about what it means to make writing centres into institutions that have a public mandate as part of the university's public educational mission. I felt that Barnett and Girgensohn were less interested in reconciling the values of academic capitalism with the values of academic writing development but more interested in asserting the difference in the latter whether by maintaining the public function of writing and writers against geo-political manoeuvring (Barnett) or by doing institutional work in order to build communities of writing and secure professional legitimacy (Girgensohn). 
The attention given to the policies and politics of academic writing during EATAW 2017 was significant. However, it was also during EATAW 2017 when I realised that the ongoing privatisation and corporatisation of academic writing development was real and potentially inevitable; it was, after all, being embraced by a collective that, through its very mission, aims to be inclusive, and public. At what costs did privatised writing development have a presence at EATAW? Was that embrace symptomatic of an emergent trend or simply a natural manifestation of an existing condition at the heart of our academic writing institutions, where the sponsorship of writing, to use Deborah Brandt's term (2005, 2015), is, by its very nature, marketable, transacted and commodified? Members of the European academic writing collective who convene every other year in different universities across Europe are based at academic organisations that are not all fully subscribed to the imperatives of privatised, neoliberal higher education; in short, they are public universities. So why assume otherwise? Did the location of the conference in the UK, an outpost of academic capitalism (Slaughter and Leslie 1997), then make a difference? Were the privatised initiatives represented at the conference all based on the same socio-economic model? What were the differences and implications? Should the academic community be more mindful or sceptical of such initiatives, some of which sit outside academic institutions, others on the outskirts of academia, although both fully rely, for their very existence, on the requirements of writing produced in universities?

\section{Mainstreaming Privatised Writing Development: A Problematic}

There were three triggers at EATAW 2017 for my questioning. The first was Anchorage Education or Anchorage Educational Services, the writing retreat business spin-off glossed over by Rowena Murray in her keynote as a natural outcome of her work at the University of West Scotland (although the university logo does not feature on the company's webpages). The enterprise offers writing retreats and writing retreat training based on Murray's influential work in this area. The second was Epigeum, one of the conference sponsors, a corporate consortium of partnering universities and provider of educational online products, including academic writing-related goods. Originating at Imperial College and facilitated by Oxford University Press, Epigeum boasts a suite of courses related to researcher development in general which, if taken, ensures the so-called 'Epigeum advantage'. The third was a talk by Sara Mathieu-Chartier (EATAW 2017a: 54) on 'measuring behaviour changes during and after a writing retreat'. The talk stemmed from a project, conducted in collaboration with Larissa Kempenaar via the Thèsez-vous? writing retreat activities for research students, as part of a non-profit organisation, Blitz Paradisio, 'dedicated to the management of writing events and activities for graduate students across all universities and areas of specialisation' (Thèsezvous? n.d.).

All three enterprises were rather marginally mentioned at the conference and yet, through their inclusion, mainstreamed by their contexts: Anchorage Education was only a quick mention, yet in the opening keynote; Epigeum, only a leaflet on a tableful of advertisements, yet an important conference sponsor; Thèsez-vous?, a mere literacy event amongst many others discussed during the conference parallel panels, yet the backdrop to a transatlantic research project on writing behaviour. Based on their websites, there are differences in the ways in which these privatised initiatives function on a spectrum of profitability and inclusivity and sell the experience and knowledge of writing. The non-profit, student-run Blitz Paradisio gives a sense of community-minded work and accessibility. The small business appearance of Anchorage Education promotes the socially private, privileged experience of the writing retreat (the bluebells of Scotland are a useful trope). Epigeum, with its cosmic connotations, is downright corporate in the language of its advertisements and cold metaphors of capitalist-minded education: flexible, innovative, technologically driven.

These initiatives are not new or unique. They fit the story of writing development's significant role in the establishment of market-driven Western academia (see Bousquet's powerful demonstration in his 2002 article, 'Composition as Management Science'). Nor are they uniquely corporate. Organisations like the Society for Research in Higher Education (SRHE) also commission paid-for writing development activities for researchers. Universities are both clients and suppliers of writing consultancy. I have also been a willing customer. For instance, 
the insights and advice received during one of these events were valuable in the very early stages of writing my book proposal which later became a monograph. I do not, therefore, intend to belittle their contribution to writing development especially where any form of advisory work is absent locally. To take my cue from Bruce Horner (2015: 454), I do not wish to raise problems but to address the open-ended problematic of privatised writing development via four interrelated points that colleagues can further unpack in their responses: conditions of privilege and access; the curriculum of corporate writing development in light of university-based writing programmes; impact on the material conditions of university-based academic writing labour (competition and displacement); and finally, potential ways of forging coalitions that may lead to genuine collaboration and changes in the writers' academic literacies and public engagements with writing development.

The question of privilege and access is a fundamental one. If labour and monetary resources for writing development at local academic institutions are scarce, then investment in paid-for interventions is not possible and neither is indiscriminate support across the disciplines and levels of experience (Geller and Eodice 2013: 6). Resources, limited as they may be, will be inevitably channelled where the production of writing is high stakes, for instance, when developing writing that is classified and exchanged for rankings, tenure track or institutional evaluation. Moreover, writing brokering that exists behind a pay wall is sure to create a sense of socio-economic and educational inadequacy and a material condition of disadvantage, especially on the international academic scene. It must be said that the existence of writing development enterprises is also the outcome of academic labour structures, in the sense of a labour spill-over from academia into entrepreneurship (whether this is a sign of systemic failure or academic resourcefulness and flexibility is another story). Another consequence of this phenomenon could be an escalation of the privatisation trend, in the sense that public academic institutions would actively seek to align themselves to the demands of the academic market and with other institutions that employ similar strategies of professional writing development to enhance their competitiveness. The on-and-off buying and selling of writing services would then become the convenient norm in place of steady investments in local writing development programmes.

It may be useful to draw up a map of existing private writing development companies and their contractual relations with universities to complement directories of university academic writing provision of the kinds that Lisa Ganobcsik-Williams introduced at the conference (EATAW 2017a: 34) or that are published in books like Writing Programs Worldwide: Profiles of Academic Writing in Many Places (Thaiss et al. 2012). In this way, one could establish whether there is a correlation between the absence of writing development programmes and the hiring of services. This is important not least because labour conditions locally in academic institutions may also be affected by the outsourcing of external writing services. Different forms of labour displacement may occur if writing developers already engaged in support programmes internally are bypassed in favour of external experts carrying other indices of prestige or professional credibility, like former affiliations to publishing houses.

A qualitative mapping could also trace the routes and modes of influence and transmission of certain models of academic literacies. Is a standardised, technical, non-disciplinary mode of understanding writing proliferated through these privatised services? To what extent does research in academic writing play a part in these transmissions? If 'scholars of literacy frequently explain their motives, theories and practices within national, regional or transnational research' (Thaiss 2012: 10), how do writing entrepreneurs justify their practices and ideologies of writing? Writing programmes in universities are evaluated, monitored and reviewed in keeping with certain standards of academic quality assurance, benchmarking exercises and not least research projects. Equally, private interventions must also undergo qualitative scrutiny beyond surface features of success, such as customer satisfaction responses or the private developers' default indicators of status.

Finally, if we consider the accelerated privatisation of writing development inevitable and hard to resist, we must then envision alternatives in which productive alliances can be forged between universities and writing development businesses whereby universities can also regulate such interventions instead of simply importing them. Regulation would help forestall 
internal labour displacements and create participatory immersive writing environments, which are critical spaces mindful of individual and disciplinary writerly identities. It would also ensure that access to this infrastructure of support is more open to writers and institutions that cannot afford it. Alliances could be achieved through open and transparent communication prior to any intervention, by assessing needs and understanding the local demands on writing and the local conditions of writing development. Ultimately, universities need to make sure they only use external discrete interventions to kickstart longitudinal, deep engagements with writing internally, via 'dwelling-focused' practices (Lamos 2017: 47). Such practices could include writing groups, writing retreats, sustainable protected writing time in studios or peer reviewing networks that nurture disciplinary or interdisciplinary communities of writers. In keeping with a simple trickle-down mechanism, alongside for-profit interventions, ways of delivering pro bono writing development could also be designed and implemented either locally or outside of local or national academic contexts. This would maximise the affordability of writing development by putting policies and institutional configurations to good use in order to serve academic communities beyond profit-making, gatekeeping and competition.

There may be a high dose of idealism in this projection. However, in the spirit of academic activism, imagining radical alternatives is crucial to securing more rights to academic literacies, or at least to getting the conversation started. Noticing the presence of these writing development enterprises at EATAW2017, I wondered if it was just my political sensibility playing out. To what extent do colleagues experience the rise in for-profit writing teaching and development in their own academic contexts, especially in contexts outside of the AngloAmerican space? How does this rise affect the trajectories and identities of their own local writing programmes? Which categories of academic writers are mostly targeted by these privatised interventions: students or researchers? Do colleagues feel it is necessary to preserve the public mission of our writing development institutions or is this trend a truly unavoidable, even needed, outcome of existing neoliberal structures of academic experience? Are there other consequences or issues than those I have sketched here? Any other modes of mitigation? What kinds of institutional policies do we need to help create or revise in order to respond to this trend? What kinds of politics do these policies need to reflect? Radical, resistant and revisionary, or malleable, affable and acquiescent?

As Horner, Nordquist and Ryan's recent volume on Economies of Writing (2017) shows, forprofit writing interventions have already started to catch our research imagination. In writing this piece, I have been left wanting more empirical evidence, collected, analysed, and systematised through research on the ground. This is a provocation to myself but also to the rest of the community to research the material and discursive reality of privatised writing development and the ways in which it influences the production of writing and writing development practices in universities. Then, our assumptions and conclusions would also be more fully supported, our modes of action more justified. 


\section{References}

Abraham, M. (2016) 'Rhetoric and Composition's Conceptual Indeterminacy as PoliticalEconomic Work'. College Composition and Communication 68 (1), 68-97

AILA ReN and BAAL PAWBL SIG (2018a) Our State of Knowledge about Academic Publication Practices: Welcome [online] available from $<$ https://groups.google.com/forum/\#!topic/aila-pub-ren/Xi7IKOWbJoA> [1 March 2018]

AILA ReN and BAAL PAWBL SIG (2018b) Our State of Knowledge about Academic Publication Practices: Academic Labour [online] available from $<$ https://groups.google.com/forum/\#!topic/aila-pub-ren/E3BoG3hQI8g> [1 March 2018]

AILA ReN and BAAL PAWBL SIG (2018c) Our State of Knowledge about Academic Publication Practices: Third Paper [online] available from $<$ https://groups.google.com/forum/\#!topic/aila-pub-ren/aq8LXrO5M8Y> [1 March 2018]

Anchorage Education (n. d.) Writing Retreats for Academic Writing [online] available from <http://www.anchorage-education.co.uk/> [1 March 2018]

Bennett, K. (ed.) (2014) The Semi-Periphery of Academic Writing: Discourses, Communities and Practices. New York: Palgrave MacMillan

Bousquet, M. (2002) 'Composition as Management Science: Toward a University Without a WPA'. JAC 22 (3), 493-526

Brandt, D. (2017) 'Afterword: Lessons Learned'. in Horner, B., Nordquist, B. and Ryan, S. M. (eds.) Economies of Writing: Revaluations in Rhetoric and Composition. Logan: Utah University State Press: 269-271

Brandt, D. (2015) The Rise of Writing: Redefining Mass Literacy. Cambridge: Cambridge University Press

Brandt, D. (2005) 'Writing for a Living: Literacy and the Knowledge Economy'. Written Communication 22 (2), 166-197

Cardenás, M. L. and Rainey, I. (2017) ‘Publishing from the ELT Periphery: The Profile Journal Experience in Colombia'. in Curry, M. J. and Lillis, T. (eds.) Global Academic Publishing: Policies, Perspectives and Pedagogies. Clevedon, UK: Multilingual Matters: 151-165

Donahue, C. (2009) "'Internationalization" and Composition Studies: Reorienting the Discourse'. College Composition and Communication 61 (2), 212-243

EATAW (2017a) Abstract Booklet [online] available from <http://eataw2017.org/wpcontent/uploads/2016/04/EATAW-2017-Abstract-booklet-3.pdf> [1 March 2018]

EATAW (2017b) Recorded Sessions [online] available from <http://eataw2017.org/index.php/recorded-sessions/> [1 March 2018]

Eodice, M., and Geller, A. E. (eds.) (2013) Working with Faculty Writers. Logan: Utah State University Press

Horner, B. (2015) 'Rewriting Composition: Moving Beyond a Discourse of Need'. College English 77 (5), 450-479

Horner, B. (2000) Terms of Work for Composition: A Materialist Critique. Albany: State of New York University Press 
Horner, B., Nordquist, B. and Ryan, S. M. (eds.) (2017) Economies of Writing: Revaluations in Rhetoric and Composition. Logan: Utah University State Press

Hyland, K. (2016) 'Academic Publishing and the Myth of Linguistic Injustice'. Journal of Second Language Writing 31, 58-69

Lamos, S. (2017) 'Dwelling Work and the Teaching of Writing: Responding to the Pressures of For-Profit Instruction'. in Horner, B., Nordquist, B. and Ryan, S. M. (eds.) Economies of Writing: Revaluations in Rhetoric and Composition. Logan: Utah University State Press: $43-54$

Lefebvre, H. (1968) Le droit à la ville. Paris: Anthropos

Lillis, T. and Curry, M. J. (2010) Academic Writing in a Global Context: The Politics and Practices of Publishing in English. London: Routledge

Moreno, A. I., Rey-Rocha, J., Burgess, S., López-Navarro, I. and Sachdev, I. (2012) 'Spanish Researchers' Perceived Difficulty Writing Research Articles for English Medium Journals: The Impact of Proficiency in English Versus Publication Experience'. Iberica $24,157-184$

Oxford University Press (n.d.) About Epigeum [online] available from $<$ https://www.epigeum.com/epigeum/> [1 March 2018]

REF (2014) Research Excellence Framework: Assessment Criteria and Level Definitions [online] available from

<https://www.ref.ac.uk/2014/panels/assessmentcriteriaandleveldefinitions/> [ [ July 2018]

SIGJ2 Writing Collective (2012) 'What Can We Do? The Challenge of Being New Academics in Neoliberal Universities'. Antipode 44 (4) 1055-1058

Slaughter, S. and Leslie, L. L. (1997) Academic Capitalism: Politics, Policies and The Entrepreneurial University. Baltimore: Johns Hopkins University Press

SRHE (2018) Past Event Details: Academic Writing Skills [online] available from <https://www.srhe.ac.uk/events/details.asp?eid=339> [1 March 2018]

Thaiss, C. (2012) 'Origins, Aims and Uses of Writing Programs Worldwide: Profiles of Academic Writing in Many Places'. in Thaiss, C., Bräuer, G., Carlino, P., Ganobcsik-Williams, L. and Sinha, A. (eds.) Writing Programs Worldwide: Profiles of Academic Writing in Many Places. Anderson, SC: Parlor Press: 5-22

Thaiss, C., Bräuer, G., Carlino, P., Ganobcsik-Williams, L. and Sinha, A. (2012) Writing Programs Worldwide: Profiles of Academic Writing in Many Places. Anderson, SC: Parlor Press

Thèsez-vous? (n. d.) About Us [online] available from <http://www.thesez-vous.com/aboutus.html> [1 March 2018] 